\title{
Comprehending the intention to use branchless banking by rural people during the corona pandemic: evidence from Bangladesh
}

\author{
Mohammad Ali Ashraf ${ }^{1}$ (D)
}

Received: 12 December 2020 / Revised: 29 November 2021 / Accepted: 21 December 2021 / Published online: 9 February 2022

(c) Springer Nature Limited 2022

\begin{abstract}
The banking sector can take advantage of the proliferation of online banking as well as government's reinforcement of cashless transactions to expedite the usage of branchless banking. The prime objective of this study is to examine the factors that affect rural people's bounded rational intention toward branchless banking conduct during this Corona Pandemic in Bangladesh. In doing so, the theory of bounded rational intention was used as its theoretical background. Data $(n=390)$ were collected from the people residing in the rural areas surrounding branchless banking booths where no branch banking services are available. Data were analyzed employing structural equation modeling by AMOS software. The findings of the study indicate that all factors are positively significant to influence the rural people's bounded rational intention toward branchless banking behavior. The results also show that trustworthiness and normative structure exhibit the highest positive significance to influence people's bounded rational intention. It implies that the agents ought to be trustworthy for popularizing the branchless banking services in the rural areas. The outputs of this study provide insight into branchless banking services which will help banks and financial institutions formulate right policy on branchless banking strategy.
\end{abstract}

Keywords Trustworthiness $\cdot$ Normative structure $\cdot$ Self-efficacy $\cdot$ Bounded rational intention $\cdot$ Branchless banking service

\section{Introduction}

The whole world has been combating the Corona Pandemic since the first quarter of the year, 2020. In order to control this Pandemic, many countries including Bangladesh have followed the policy of complete lockdown which hit the daily life of all their citizenry. In Bangladesh, three patients affected by the Corona Virus were identified for the first time in the capital on March 8, 2020. On March 26, 2020 the country had decided to shut down completely and since then, people are largely staying home except few emergency needs while most of the business organizations including commercial banks were closed.

Branchless banking (or agent banking) is one of the cutting-edge financial innovations in this new millennium (Chowdhury 2018; Khan and Woodard 2016; Siddiquie 2014). This type of banking has been introduced mostly because there are a large number of rural people who are

Mohammad Ali Ashraf

mashraf@eco.uiu.ac.bd

1 Department of Economics, United International University, Madani Avenue, Gulshan, Dhaka, Bangladesh outside formal banking services (Ahmed and Ahmed 2018; Hinson 2011). The Central Bank in Bangladesh (Bangladesh Bank) has issued formal broad guidelines on branchless banking on December 9, 2013 (Bangladesh Bank 2013). However, branchless banking has been started at the first time by commercial banks in 2016 (Chowdhury 2018; Islam 2018). In reality, branchless banking is regarded as an alternative banking service like other types of online banking permitted by the Government of Bangladesh to integrate more unbanked rural people in its financial surface (Nisha et al. 2020; Khan and Woodard 2016).

In Bangladesh, branchless banking has witnessed a quite consistent growth pattern before and after the outbreak of Corona Pandemic. The latest report of Bangladesh Bank (2020) shows that there are 7.6 million accounts associated with branchless banking representing an annual growth of 114 percent in both urban and rural areas (see Fig. 1). However, this growth is substantially taking place in rural areas accounting for 113 percent from July 2019 to July 2020 compared to only 60 percent in the urban areas (Bangladesh Bank 2020). According to Bangladesh Bank (2020), a total of 28 banks have branchless banking license, but only 23 banks are in operation. Bank Asia has the largest number 
Number of accounts (in millions) associated with Agent Banking

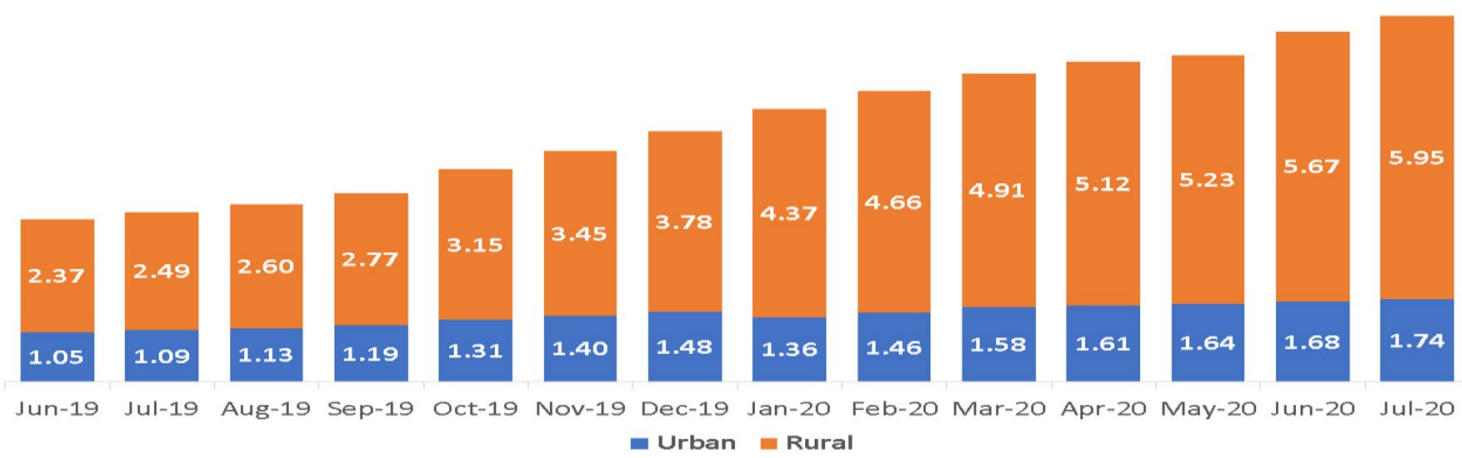

Fig. 1 Growth of the number of accounts associated with agent banking ( Source: Bangladesh Bank 2020)

of clients accruing 3 million accounts opened through branchless banking with a market share of 40.8 percent. This leading position of the market share of Bank Asia is trailed by Dutch-Bangla Bank Limited (DBBL) with 33.5 percent, Islami Bank Bangladesh Limited with 10.23 percent, Al-Arafah Islami Bank with 3.6 percent, and Agrani Bank Limited with 2.56 percent shares. Another report of the World Bank (2017) reveals that only about 40 percent of people over 15 years of age in rural Bangladesh possess an account at a bank or a financial institution. This situation has not changed too much aftermath and a huge number of people are still not having any account in branchless banking services (Chowdhury 2018). Although the growth of the number of branchless banking during the last financial year is positive, still it is not growing in a larger pace. It is also interesting to observe that this growth rate is steadily rising over the Corona Pandemic period as well. However, empirical research in this domain of branchless banking participation behavior in both rural and urban areas is crucially scarce. This fact necessitates examining the factors that affect the participation of people in branchless banking in Bangladesh. Thus, the present research offers its contribution to fill up this extant research gap in the domain of rural people's intention toward participation in branchless banking in the context of Bangladesh.

The prime intent of this paper is, therefore, to understand the intention of the rural people in branchless banking services in Bangladesh during the Corona Pandemic. In particular, how do individual beliefs about trustworthiness of branchless banking, normative structure of social pressure and self-efficacy affect individual intentions to make digital banking during the current Corona Pandemic? To answer this question, the study employs the theory of bounded rationality (TBRPB; Ashraf 2018) as its theoretical background to test different associations between the variables of concern. Data $(n=390)$ were gathered through face to face interview during the months of July and August 2020 from the rural areas of Dhaka district where there is no formal branch banking services. During this period in Bangladesh, the Corona outbreak was relatively dim. This study is important in terms of comprehending the drivers of people's branchless banking intention in Bangladesh and the result of which would help the bank authorities and policy makers formulate proper policy niche to promote branchless banking to people in remote rural areas of the country.

The contents of the paper are outlined as follows: the next section delineates the introduction and overall network spread in Bangladesh. Then, the theoretical background has been explained along with the relevant literature related to different factors included in the research framework. The research framework and hypotheses are outlined next. Later, the discussion follows the research design and the findings of the study. Finally, an interpretation of the results and their relevant implications conclude the paper.

\section{Branchless banking in Bangladesh: a concise outline}

Branchless banking has been referred to as the banking services delivered to the unbanked people residing in remote rural areas outside regular bank branches by engaged agents under a legal agency contract (Bangladesh Bank 2020). As mentioned earlier, though Bangladesh Bank has released its approval to the branchless banking scheme in Bangladesh in the end of December 2013, it was implemented in the year 2016. These types of banking services are extended to the remote rural areas where the banks find it difficult to establish any formal bank branch. The agents who provide banking services are actually nonbank agents such as grocery stores, retail outlets, post offices or pharmacies (Ahmed and Ahmed 2018). 
The growth of branchless banking has been augmented in Bangladesh to a greater extent during the outbreak of Corona Pandemic (see Fig. 2). The government of Bangladesh declared two months public holiday and restricted commercial banking operations which ended on May 30 to stop the further spread of COVID-19. However, branchless banking operations were excluded from this restriction. So, the majority of agents decided to continue operations which provided opportunities to their customers to carry out transactions at the agent outlets. Besides, the government announced BDT 1.0 trillion (USD 12 billion) mitigate the economic effects of COVID-19. The government also opened social safety nets to financially assist the vulnerable populations located in the rural areas. For disbursing these funds directly to the affected people, branchless banking became a reliable media. People in the remote rural areas became more conscious and accepted branchless banking as a trusted means of financial services. As a result, the number of accounts in branchless banking and its volume of transactions increased (Huda et al. 2020). Notably, the present research was conducted more generally for both loan and savings products rather than specifically for one of these products.

However, the situation of loan disbursement through branchless banking outlets was low in spite of increasing number of deposits (see Fig. 3). This low loan to deposit ratio is the result of missing out on providing loans to Cottage, Micro, Small and Medium Enterprises (CMSMEs). There have been a couple of reasons for missing out on providing credits to CMSMEs. Firstly, banks take lengthy time to process these loan applications usually from 7 to 10 days. This lengthy process makes branchless banking unattractive to SMEs for financing as the credit from Microfinance Institutions (MFIs) can be availed at a faster rate. Secondly, banks also find it unattractive to provide credits to SMEs, because of capping the lending rate to 9 percent and deposit rate to 6 percent by the government in April 2020. So, banks find these credits to SMEs more non-appealing. For these reasons, loan disbursement through branchless banking was low.

\section{Number (in million) and Volume (in BDT billion) of Agent Banking} Transaction

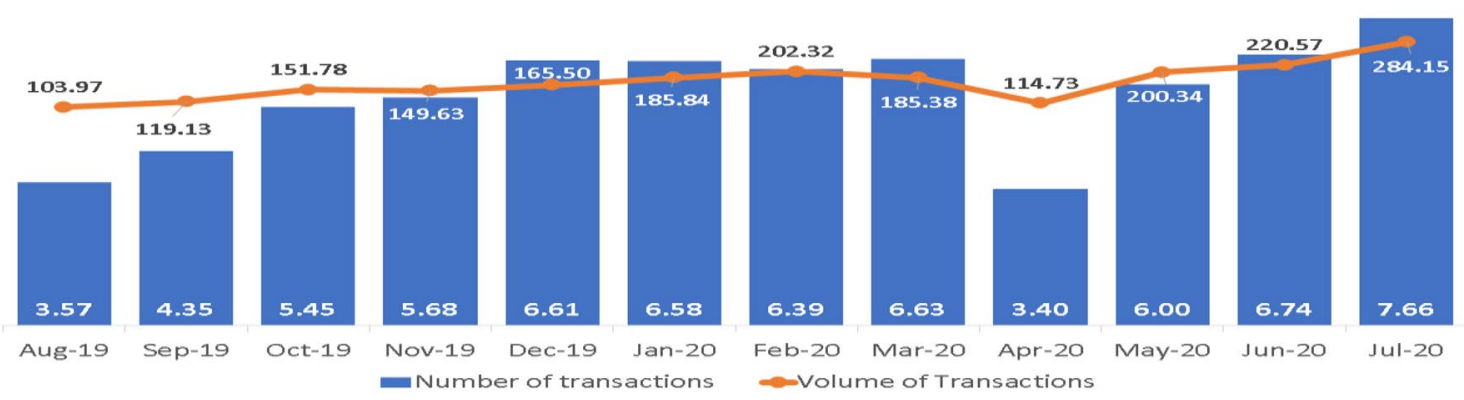

Fig. 2 Number and volume of agent banking transactions ( Source: Bangladesh Bank 2020)

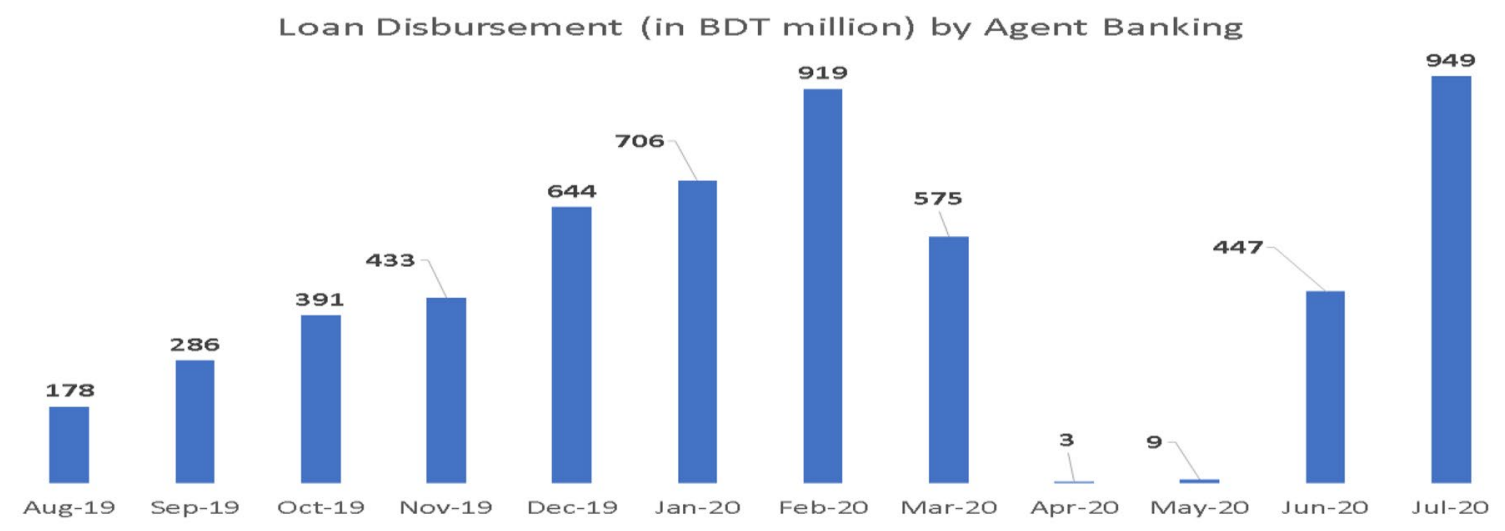

Fig. 3 Loan disbursements by agent banking outlets ( Source: Bangladesh Bank 2020) 


\section{Theoretical base}

\section{TBRPB}

The theory of bounded rational planned behavior (TBRPB; Ashraf 2018), as presented in Fig. 4, is originally a modification of the theory of planned behavior (TPB; Ajzen 1991). The rationale for this modification lies in the concept of bounded rationality expounded by Herbert A. Simon (1986a b). TPB is based on the general assumption of mainstream economics that every individual human being is infinitely and universally rational irrespective of certain specific circumstances. For instance, consumers seek utility maximization and producers look for profit maximization in all types of environments. These instances imply that human being is limitlessly self-centered or selfish in every situation. However, Simon (1986a) refutes this purview. According to him, people are realistically subjective in their choices and decisions and show bounded self-interest, bounded rationality and bounded willpower due to incomplete information, limited thinking and information processing ability and inseparable human errors (Simon 1986a 1986b; Jolls et al. 1998; Ariely 2009). In this regard, Zanoli and Naspetti (2002) put forward that TPB is unable to explain the complex and multi-dimensional human behavior in many instances which may not go through purely a generalized rational process rather it involves conflicting beliefs, values, perceptions and social interactions. In this regard, Bandura (2006) enunciates that human behavior is richly contextualized and conditionally manifested.

So, Ashraf (2018) supports these purviews about the limitations of TPB's generalized notion and followed the arguments of bounded rationality advanced by Simon (1986a). Simon's objective is actually to strengthen the predictive and analytical power of economic theory in which any action is presumed to be consequential rather than calculated (Jolls et al. 1998; March 1978). According to March (1978, p. 593), "systematic rationality is not intentional". So, every human individual performs actual behavior depending on the subjective and bounded rationality that is conditional or bounded with its specific end (March and Olsen, 1976). Thus, Ajzen's (1991) general economic notion of universal rationality has been replaced by Simon's (1986a) bounded rational intention toward actual behavior in Ashraf's TBRPB (Ashraf, 2018). However, the bounded rational intention's three original antecedents such as attitude, subjective norms and perceived behavioral control remain similar to TPB. Nevertheless, TPB is enunciated by Ajzen (1991) as a general theory and in the same way TBRPB has also been stipulated as a general one. Thus, it does not stipulate the specific beliefs that are related to any specific behavior, so outlining those beliefs remains up to the researchers. Hence, the present research has identified trustworthiness as an important factor to have influence on attitude toward bounded rational intention. Similarly, normative structure and self-efficacy have been set to influence subjective norms and perceived behavioral control, respectively which in turn influence bounded rational intention toward the rural people's branchless banking behavior.

\section{Research model and hypotheses development}

The research model (see Fig. 5) employed in the study is based on the theoretical base namely TBRPB advanced by Ashraf (2018). The behavior in question in this study is people's bounded rational intention toward participating branchless banking in the rural areas in Bangladesh. In this regard, TBRPB has been considered as an appropriate theory background for exploring people's subjective intention toward branchless banking activities. As is evident in the research framework, trustworthiness, normative structure and self-efficacy are set as explanatory variables to affect attitude, subjective norms and perceived behavioral control
Fig. 4 Theory of bounded rational planned behavior (TBRPB). Source: Ashraf (2018)

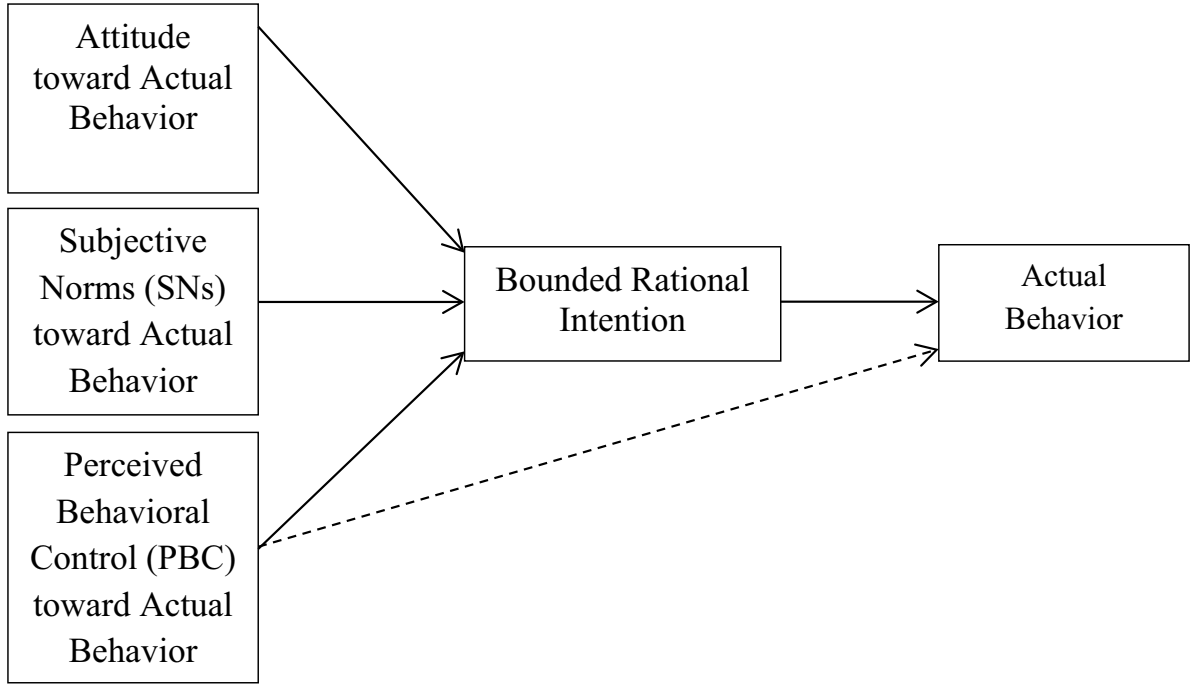


Fig. 5 Research model

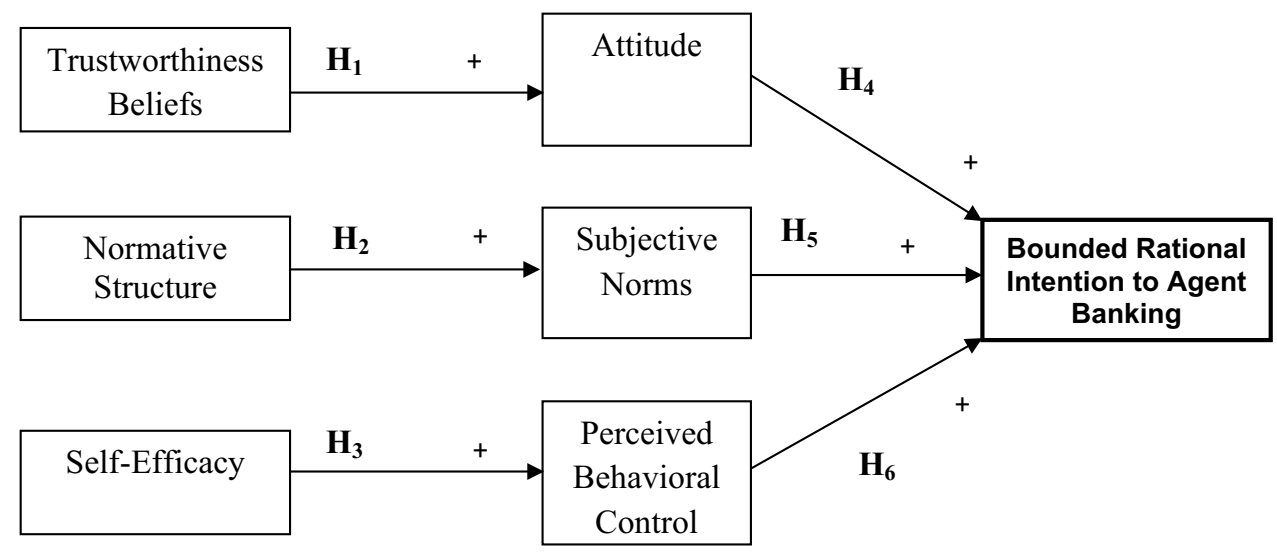

to influence bounded rational intention toward branchless banking. Based on the articulation of the research model in the study, the following hypotheses are developed to analyze the data collected from the rural people residing in the rural areas in Bangladesh during the current Pandemic.

As mentioned earlier, an underlying premise of the present study is that trustworthiness of branchless banking influences attitude toward individual's bounded rational intention to branchless banking. TBRPB outfits a robust theoretical foundation for probing such a premise along with a research model for checking whether attitude actually associated with bounded rational intention to branchless banking activities. Similarly, there is also another underlying premise of the current study that normative structure influences subjective norms to influence bounded rational intention to branchless banking activities. The last underlying premise of the study is that self-efficacy influences perceived behavioral control to influence bounded rational intent of the people toward branchless banking in the rural areas of Bangladesh.

\section{Trustworthiness}

Trustworthiness of branchless banking operation is a vital concern of the people who intend to avail that opportunity to transfer fund over the Internet (Sekhon et al. 2014; Corritore et al. 2003). As many people residing in rural areas might distrust the agents of online banking operations, because people's personal information must be shared in this process. According to (Ratnasingham 1998), trust takes place only when those involved are guaranteed of other people's preparedness and capability to be liable for their accountabilities. Be that as it may, many customers are observed to be worried about the trustworthiness of the branchless banking service, because financial transactions are deemed risky jobs as mobile banking or Internet shopping (Devlin et al. 2015; Jones and Vijayasarathy 1998). So, trustworthiness has been an important issue which may influence on people's attitude to their intention toward actual branchless banking online. Customer views of the trustworthiness of the branchless banking service, then, could reasonably be expected to affect their intention to participate in financial transactions by branchless banking service.

As is evident that branchless banking is a new financial innovation and much empirical research on this topic particularly in the context of Bangladesh is sparse. Yet, there have been a large number of studies on mobile/online/Internet banking in which trustworthiness plays a significant role (Singh and Srivastava 2020; Hu et al. 2019; Yuan et al. 2019; Alkailani 2016; Yu et al. 2015; Nasri and Charfeddine 2012; Devi et al. 2012; Zhao et al. 2010; Tan and Teo 2000; Mukherjee and Nath 2003). These empirical research works mainly focused on online or mobile banking and found trustworthiness or reliability (security) as an important variable to influence positively customers' attitude toward their intention. Thus, it can be postulated that.

H1 Trustworthiness is positively associated with people's attitude toward bounded rational intention to perform branchless banking.

\section{Normative structure}

Normative structure refers to the beliefs about how important referent others feel about actual behavior, and motivation to comply with the views of important others, perceptions of the social pressure to conform to anticipations about involving in the behavior, ought to also influence intention to perform that concerned behavior in question. With a few exceptions, the social science literature conceives of normative structure as exogenous variables (Bicchieri 2006). There have been several studies that carried out in different fields and incorporate normative structure as an influencing catalyst to subjective norms such as Internet purchase (George 2004), Internet banking (Ashraf et al. 2010), organic food purchase (Ashraf 2019a), halal food purchase (Ashraf 2019b). These studies show that there is a positive significant link between normative structure and subjective norms toward the actual behaviors in different contexts. Thus, it can be hypothesized that. 
H2 Normative structure is positively associated with subjective norms toward people's bounded rational intention to perform branchless banking.

\section{Self-efficacy}

As a concept, self-efficacy has been expounded by Bandura (1994). According to Bandura (1994, p. 1), "perceived selfefficacy is defined as people's beliefs about their capabilities to produce designated levels of performance that exercise influence over events that affect their lives. Self-efficacy beliefs determine how people feel, think, motivate themselves and behave." A robust sense of efficacy pushes up human performance as well as personal well-being in several ways (Bandura and Adams 1977; Bandura 2006). Individuals with high confidence in their abilities try to accomplish tough jobs and take them as challenges rather than to be frightened or to be avoided (Bandura 1997).

Ajzen (1991) equates Bandura's (1994) perceived selfefficacy to perceived behavioral control. However, several empirical studies employ perceived self-efficacy as an antecedent of perceived behavioral control such as Taylor and Todd (1995), George (2002), George (2004), Ashraf et al. (2010), (Ashraf 2019a) and Ashraf (2019b). The findings of these studies indicate that perceived self-efficacy is positively associated with perceived behavioral control toward intention. Thus, it can be postulated that.

H3 Self-efficacy is positively associated with perceived behavioral control toward people's bounded rational intention to perform branchless banking.

The remaining three hypotheses were derived directly from TBRPB. Positive attitude toward any specific behavior ought to result positively in the conduct of that behavior. Numerous empirical studies show that attitude has a positive association between attitude and intention toward actual behavior in question (Khalifa and Limayem 2003; Pavlou 2002; Suh and Han 2003; Song and Zahedi 2001; Ashraf, $2019 \mathrm{a}, \mathrm{b})$. The results of these research works demonstrate that attitude is positively related to intention toward actual behavior. Thus, it can be hypothesized that.

H4 Attitude is positively associated with people's bounded rational intention to perform branchless banking.

According to TBRPB, subjective norm is the perceived social pressure to perform or not to perform the behavior (Ashraf 2018). If social anticipations are that individuals ought to involve in the behavior in question, then they ought to be more likely to do the same. In the contrary, if social anticipations are that individuals ought to not involve in the behavior, then they ought to be less likely to do the same (La Barbara and Ajzen 2020). In the present context of the study, if branchless banking operation is perceived to be socially desirable behavior, depending on what significant others ponder about it, the individual is more likely to carry out branchless banking activities. Many empirical studies reveal that subjective norm is positively linked to people's intention toward actual behavior (Taylor and Todd, 1995; George 2004; Ashraf et al. 2010; Ashraf, 2019a; Ashraf, 2019b). Thus, it is postulated that.

H5 Subjective norm is positively associated with people's bounded rational intention to perform branchless banking.

In TBRPB intentions are anticipated to predict behavior to the extent that the actor is capable of carrying out the behavior, i.e., to the extent that actual control over behavioral performance is high (Ashraf 2018). Perceived behavioral control is thus posited to predict bounded rational intention to perform the actual behavior in both TBRPB and TPB. Empirical research works report that perceived behavior al control is positively related to people's intention toward the behavior in question (Taylor and Todd, 1995; George 2004; Ashraf et al. 2010 2019; Ashraf 2019). Thus, the following hypothesis is postulated as.

H6 Perceived behavioral control is positively associated with people's bounded rational intention to perform branchless banking.

\section{Research methods}

\section{Measures}

Conforming to the objectives of the present study, a survey instrument was developed. The measures of the constructs of the study were adapted from existing literature and a slight modification was made to better suit the context. As such, 4-items of attitude, 6-items of normative structure, 2-items of subjective norms, 3 -items of perceived behavioral control and 4-items of self-efficacy were adapted from Taylor and Todd (1995) and 6-items of trustworthiness were sourced from Jarvenpaa et al. (1998). Besides, 2-items of bounded rational intention toward branchless banking were taken from Ashraf (2018). A 7-point Likert scale was employed to detect the answers for each question of the constructs. In the next step, before administering the final survey, the questionnaire was piloted with 30 respondents.

\section{Sample and data collection}

The sample size for this research was selected following the sampling formula provided by Cochran's (1977). According to Cochran (1977), a total of 384 data are adequate for infinite population. Owing to non-availability of any recognized list of 
residents in the data collection sites, the authors approached to potential respondents more systematically at the rural households. The rural people who reside around the branchless banking booth were approached for data collection for this study. The respondent intercept technique, one of the widely accepted convenience sampling methods to capture the consumer behavior, was utilized to gather necessary data. One person from each household was selected to interview face to face. Each interview was held for about 30-35 min on an average. The persons who refused to provide the data were skipped and next door was solicited. A total of 400 questionnaires were secured with valid responses. However, finally 390 questionnaires were selected for data analysis excluding 10 questionnaires which were found to be inconsistent and erroneous.

\section{Data analysis}

For the primary data screening purpose and to inspection of the issue of non-response partiality, common method bias (CMB), and the demographics of the participants, the version 22 of the Statistical Packages for Social Science (SPSS) was applied. The analyses also determined descriptive statistics along with the measures of skewness and kurtosis correlation coefficients, different reliability and discriminant validity tests. Later on, the assumed relations were statistically scrutinized with the help of AMOS-20 software by following structural equation modeling (SEM) technique. Then, following Hair et al. (2010), two sequential steps were carried out. Firstly, the measurement model was evaluated for exploratory factor analysis (EFA) and secondly, the structural model was assessed for confirmatory factor analysis (CFA). This study uses the significance levels of $p<0.001, p<0.05$ and $p<0.10$ based on the guidance provided by Fisher (1950, p. 80), who asserts that there cannot be a standard or conventional level of significance which rather ought to be more flexible, so determining those significance levels is left up to the researchers.

\section{Results}

Table 1 illustrates the demographics of the participants in details.
Table 1 Demographic profiles of the respondents

\begin{tabular}{|c|c|c|}
\hline Characteristics & $n$ & Valid percent \\
\hline \multicolumn{3}{|l|}{ Gender } \\
\hline Female & 257 & 66 \\
\hline Male & 133 & 34 \\
\hline \multicolumn{3}{|l|}{ Age (Years) } \\
\hline $15-25$ & 39 & 10 \\
\hline $26-30$ & 59 & 15 \\
\hline $31-35$ & 176 & 45 \\
\hline $36-45$ & 97 & 25 \\
\hline Above 45 & 19 & 5 \\
\hline \multicolumn{3}{|l|}{ Marital status } \\
\hline Single & 125 & 32 \\
\hline Married & 250 & 64 \\
\hline Divorced & 15 & 4 \\
\hline \multicolumn{3}{|l|}{ Religion } \\
\hline Islam & 343 & 88 \\
\hline Hindu & 31 & 8 \\
\hline Others & 16 & 4 \\
\hline \multicolumn{3}{|l|}{ Education } \\
\hline No education & 118 & 30 \\
\hline Secondary & 186 & 48 \\
\hline Higher secondary & 67 & 17 \\
\hline Graduate /Post Graduate & 19 & 5 \\
\hline \multicolumn{3}{|l|}{ Monthly income (Bangladeshi Taka) } \\
\hline 0-15,000 (USD 200) & 175 & 45 \\
\hline 15,001-25,000 (USD 201-320) & 137 & 35 \\
\hline 25,001-40,000 (USD 321-500) & 59 & 15 \\
\hline Above 40,000 (USD Above 500) & 19 & 5 \\
\hline
\end{tabular}

Source: Study survey 
Table 2 Descriptive statistics

\begin{tabular}{lllllllr}
\hline Constructs & $n$ & Min & Max & Mean & SD & Skewness & Kurtosis \\
\hline Bounded rational intention & 390 & 1.00 & 5.60 & 2.457 & .933 & .513 & -.235 \\
Attitude & 390 & 1.36 & 7.00 & 5.193 & 1.639 & -.390 & -1.504 \\
Trustworthiness & 390 & 1.93 & 7.00 & 5.173 & 1.568 & -.072 & -.762 \\
Subjective norm & 390 & 1.00 & 7.00 & 4.599 & 1.645 & -.247 & -.957 \\
Normative structure & 390 & 1.00 & 7.00 & 4.393 & 1.358 & -.328 & -1.313 \\
Behavioral control & 390 & 1.00 & 7.00 & 4.908 & 1.264 & -.439 & -.053 \\
Self-efficacy & 390 & 1.50 & 7.00 & 4.874 & 1.083 & -.172 & -.726 \\
\hline
\end{tabular}

Table 3 Correlations, reliabilities and average variance extracted (on diagonal in bold)

\begin{tabular}{lllllllll}
\hline Constructs & Reliability & 1 & 2 & 3 & 4 & 5 & 6 & 7 \\
\hline Bounded rational Intention $(1)^{\mathrm{a}}$ & .76 & - & & & & & & \\
Attitude (2) & .92 & $.578^{* *}$ &. $\mathbf{7 6}$ & & & & & \\
Trustworthiness (3) & .93 & $.556^{* *}$ & $.839^{* *}$ &. $\mathbf{7 1}$ & & & & \\
Subjective Norm (4) & .91 & $.474^{* *}$ & $.755^{* *}$ & $.824^{* *}$ & .84 & & & \\
Normative Structure (5) & .90 & $.438^{* *}$ & $.732^{* *}$ & $.748^{* *}$ & $.755^{* *}$ &. $\mathbf{5 7}$ & & \\
Behavioral Control (6) & .81 & $.549^{* *}$ & $.444^{* *}$ & $.457^{* *}$ & $.443^{* *}$ & $.498^{* *}$ & .57 & \\
Self-Efficacy (7) & .82 & $.563^{* *}$ & $.745^{* *}$ & $.750^{* *}$ & $.751^{* *}$ & $.685^{*}$ & $.652^{* *}$ & $\mathbf{. 6 9}$ \\
\hline
\end{tabular}

**Correlation is significant at the 0.01 level (2-tailed)

*Correlation is significant at the 0,05 level (2-tailed)

aThe Cronbach's Alpha values are calculated for bounded rational intention and subjective norm which possess two items in the questionnaire and the rests have CRs
As the data for both exogenous and endogenous variables were collected from single source, it necessitates checking if there is any common method bias. Relating this issue, both procedural and statistical methods were employed. Based on the procedural technique, participants were fore-told that no right or false answer of the questions remains in the survey instrument and they were asked to provide their answers with accuracy and honesty (Chuah et al. 2017). In addition to this, the respondents were also confirmed that their responses would be aggregated to protect their privacy of participation. Following a statistical technique, the study employed Herman's single factor analysis drawing on the method provided by Podsakoff et al. (2012). The outcomes of the EFA (Exploratory Factor Analysis) reveal that 31.87 percent of the variance is explained by the generated single factor The common latent factor score is found to be 9 percent which is also in an acceptable level that there has been no measurement errors involved in the study (Podsakoff et al. Podsakoff).

Table 2 describes the descriptive statistics along with the measures of skewness and kurtosis for checking the normality in the probability distribution of the data set. The mean values of the constructs of attitude and trustworthiness were found to be the maximum among the constructs. The lowest mean value for the construct of bounded rationality. Other mean values for subjective norms, normative structure, perceived behavioral control and self-efficacy are above four. These measures indicate that the respondents are mostly positive on their responses to adopt the branchless banking procedure for financial activities. Normality is the most fundamental assumption in multivariate analysis (Hair et al. 2010). To check for normality, four measures were used in this study to measure and assess the spread of data distribution: standard deviation, mean, skewness and kurtosis. In the present study, all variables were tested for normality where the values of skewness and kurtosis were particularly examined in this respect. Hair et al. (2010) and Byrne (2010) argued that data set is considered to be normal if skewness is between -2 to +2 and kurtosis is between -7 to +7 .The measures of skewness and kurtosis are presented in Table 2 which shows that the overall values of skewness and kurtosis were within the critical acceptable ranges as the recommendations provided by both Hair et al. (2010) and Byrne (2010). Thus, the normality assumption has been assured by the data set used in the present study.

Table 3 enlists correlation coefficients, reliability indices and average variance extracted (AVE) to check about the internal consistency and convergent validity. As directed by the minimum value for Cronbach's Alpha, composite reliability (CR), and average variance extracted (AVE) is 0.70 , 0.70 , and 0.50 to confirm the reliability, internal consistency and convergent validity of the constructs, respectively. As 
Table 4 Items and Loading Values (CFA)

\begin{tabular}{|c|c|c|}
\hline Construct & Item & Loading \\
\hline \multirow[t]{4}{*}{ Attitude } & Q1: I like to perform branchless banking during the present Corona Pandemic & 0.79 \\
\hline & Q2: Performing branchless banking is a good idea during the present Pandemic & 0.91 \\
\hline & Q3: Performing branchless banking is a wise idea during the present Pandemic & 0.92 \\
\hline & Q4: Performing branchless banking would be pleasant for me & 0.86 \\
\hline \multirow[t]{6}{*}{ Trustworthiness } & Q5: Performing branchless banking is a reliable way for my family during this Pandemic & 0.90 \\
\hline & $\begin{array}{l}\text { Q6: Taking care of the safe financial matters of family through branchless banking is a good idea during } \\
\text { this Pandemic }\end{array}$ & 0.78 \\
\hline & Q7: Branchless banking system is trustworthy during this Pandemic & 0.85 \\
\hline & Q8: Putting trust in branchless banking is a good idea during this Pandemic & 0.88 \\
\hline & Q9: I believe in the honesty of branchless banking system during this Pandemic & 0.80 \\
\hline & Q10: Believing in honesty of branchless banking is a good idea during this Pandemic & 0.86 \\
\hline \multirow[t]{2}{*}{ Subjective norm (SN) } & $\begin{array}{l}\text { Q11: People who influence my behavior wouldthink that I should perform branchless banking during this } \\
\text { Pandemic }\end{array}$ & 0.92 \\
\hline & $\begin{array}{l}\text { Q12: People who are important to me would think that I should perform branchless banking during this } \\
\text { Pandemic }\end{array}$ & 0.91 \\
\hline \multirow[t]{6}{*}{ Normative structure (NS) } & Q13: My friends would think that I should perform branchless banking during this Pandemic & 0.83 \\
\hline & Q14: Generally speaking, I want to do what my friends think I should do during this Pandemic & 0.58 \\
\hline & Q15: My relatives would think that I should perform branchless banking during this Pandemic & 0.89 \\
\hline & Q16: Generally speaking, I want to do what my relatives think I should do & 0.61 \\
\hline & Q17: My parents would think that I should perform branchless banking during this Pandemic & 0.85 \\
\hline & Q18: Generally speaking, I want to do what my parents think I should do & 0.70 \\
\hline \multirow[t]{3}{*}{ Behavioral control (PBC) } & Q19: I am capable of performing branchless banking during this Pandemic & 0.78 \\
\hline & Q20: Performing branchless banking is entirely within my control during this Pandemic & 0.74 \\
\hline & $\begin{array}{l}\text { Q21: I have the resources and the knowledge and the ability to perform branchless banking during this } \\
\text { Pandemic }\end{array}$ & 0.75 \\
\hline \multirow[t]{3}{*}{ Self-efficacy (SE) } & Q22: I feel comfortable performing branchless banking on my own during this Pandemic & 0.79 \\
\hline & $\begin{array}{l}\text { Q23 For me, feeling comfortable in performing branchless banking on my own is important during this } \\
\text { Pandemic }\end{array}$ & 0.87 \\
\hline & Q25: For me, being able to purchase organic food on my own is important during this Pandemic & 0.85 \\
\hline \multirow[t]{2}{*}{ Intention } & $\begin{array}{l}\text { Q27: I intend to perform branchless banking that inspires me to do this type of banking during this Pan- } \\
\text { demic }\end{array}$ & 0.61 \\
\hline & $\begin{array}{l}\text { Q28: I plan to perform branchless banking during this Pandemic, because I will be able to avoid mass } \\
\text { gathering in the bank }\end{array}$ & 0.57 \\
\hline
\end{tabular}

shown in Table 3, Cronbach's Alpha values (for bounded rational intention and subjective norms), and $\mathrm{CR}$ values are surpassed the least required value of 0.70 , indicating that study constructs are reliable (Hair et al. 2010). In addition, the constructs' AVE values are arrays from 0.57 to 0.84 , which are above the recommended threshold level of 0.50 . Thus, all the study constructs have achieved the convergent validity (Table 4).

Items and loading values obtained from confirmatory factor analysis (CFA) are presented in Fig. 4. Moreover, the study scrutinized the validity of the constructs in terms of discrimination by following Fornell and Larcker (1981) method (see Table 5). As shown in Table 5, the coefficient of correlation value of any cell is smaller than the square root of AVE values provided on diagonal in bold in its corresponding row or column. Hence, the model is said to have a discriminant validity (Fornell and Larcker 1981). Thus, the discrimination validity among the constructs has been achieved.

In Fig. 6, the exploratory factor analysis (EFA) is presented and in Fig. 7 and Table 6, the results of CFA are represented. As mentioned earlier, the study first ran for exploratory factor analysis (EFA). Based on the suggestion by Hair et al. (2010), the factor loadings were checked and the items whose factor loadings are below the threshold level of 0.55 were excluded. As shown in Fig. 7 and Table 6, all the hypothesized relationships are significant. Most importantly, trustworthiness has positive and meaningful effect on attitude of the rural people toward bounded rational intention to participate in branchless banking $(\beta=0.94, p<0.001)$. Thus, H1 is meaningfully supported. In the same line, normative structure has also positive and strong association 
Table 5 Discriminant validity (Fornell and Larcker method)

\begin{tabular}{llllllll}
\hline Constructs & 1 & 2 & 3 & 4 & 5 & 6 & 7 \\
\hline Bounded Rational Intention (1) & - & & & & & & \\
Attitude (2) & .578 & $\mathbf{. 8 7 1}$ & & & & & \\
Trustworthiness (3) & .556 & .839 & .842 & & & \\
Subjective Norm (4) & .474 & .755 & .824 & $\mathbf{. 9 1 6}$ & & & \\
Normative Structure (5) & .438 & .732 & .748 & .755 & $\mathbf{. 7 6 0}$ & & \\
Behavioral Control (6) & .549 & .444 & .457 & .443 & .498 & $\mathbf{. 7 6 0}$ & \\
Self-Efficacy (7) & .563 & .745 & .750 & .751 & .685 & .652 & $\mathbf{. 8 3 0}$
\end{tabular}

AVE values are presented on diagonal in bold

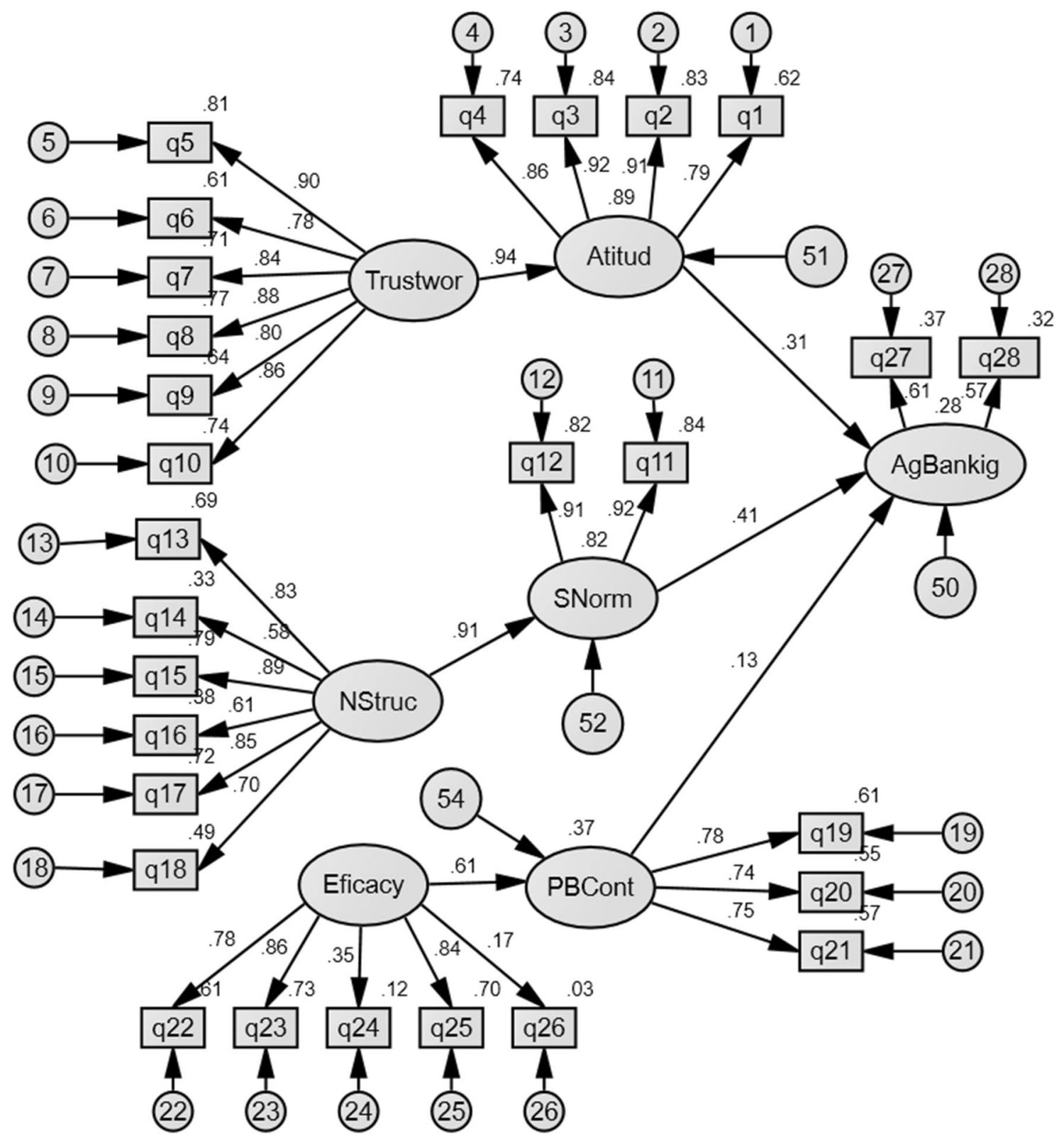

Fig. 6 Path analyses-EFA 


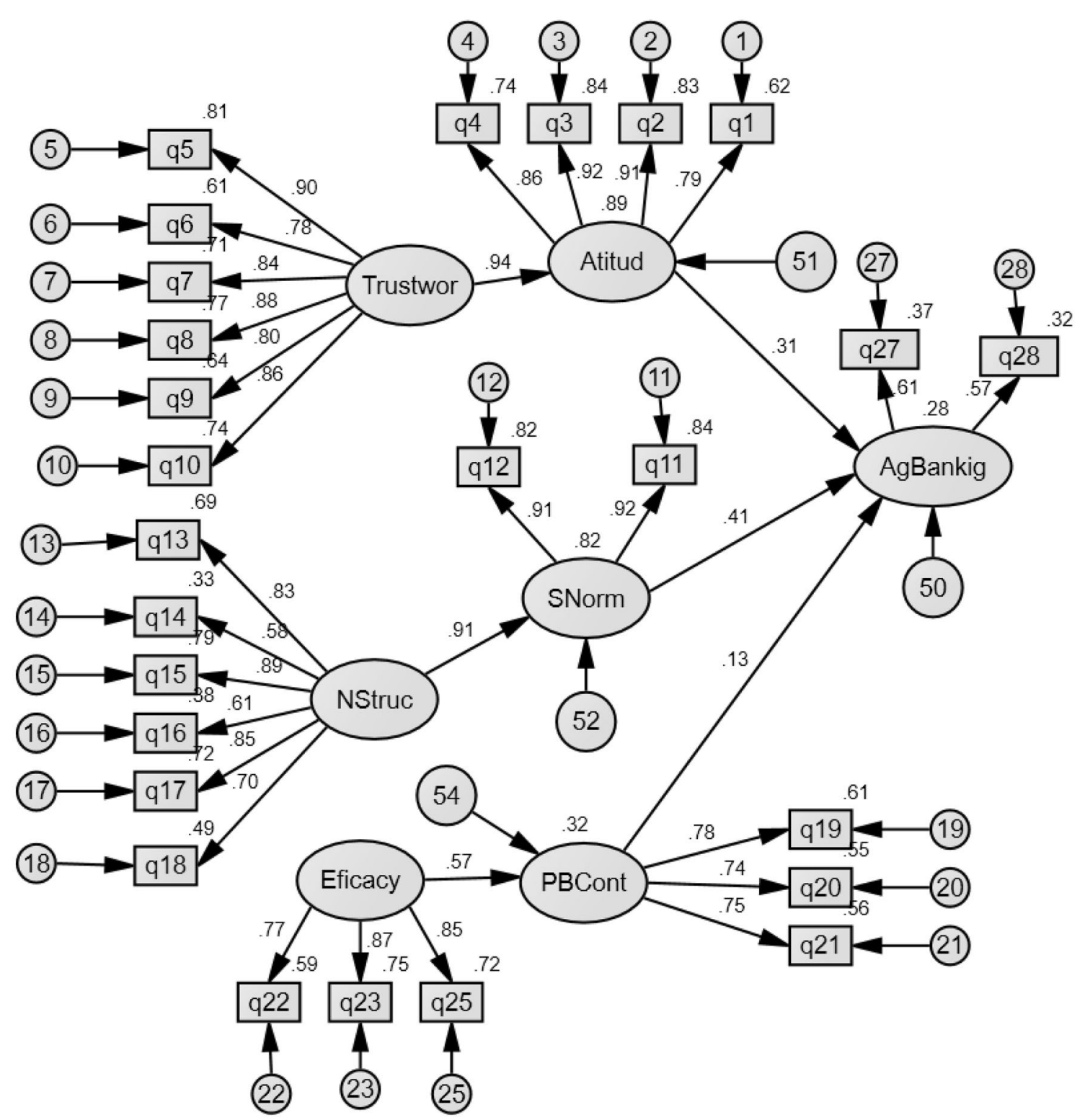

Fig. 7 Path analyses-CFA

Table 6 Path analysis based on standardized regression weights

\begin{tabular}{|c|c|c|c|c|c|c|c|}
\hline \multirow[t]{2}{*}{ Hypothesis } & \multicolumn{2}{|l|}{ Variable } & \multirow[t]{2}{*}{ Std. Estimate } & \multirow[t]{2}{*}{ S.E } & \multirow[t]{2}{*}{ C.R } & \multirow[t]{2}{*}{$p$-value } & \multirow[t]{2}{*}{ Status } \\
\hline & Endogenous & Exogenous & & & & & \\
\hline $\mathrm{H} 1$ & Attitude & Trustworthiness & 0.94 & 0.046 & 19.948 & $* * *$ & Supported \\
\hline $\mathrm{H} 2$ & Bounded Rational Intent & Attitude & 0.31 & 0.048 & 3.920 & $* * *$ & Supported \\
\hline H3 & Subjective norm & Normative structure & 0.91 & 0.085 & 14.191 & $* * *$ & Supported \\
\hline $\mathrm{H} 4$ & Bounded Rational Intent & Subjective norm & 0.41 & 0.047 & 4.918 & $* * *$ & Supported \\
\hline H5 & PBC & Self-efficacy & 0.57 & 0.056 & 8.629 & $* * *$ & Supported \\
\hline H6 & Bounded Rational Intent & $\mathrm{PBC}$ & 0.13 & 0.064 & 1.618 & $* *$ & Supported \\
\hline
\end{tabular}

$* * *$ Significant at $p<0.001$ level and $* *$ significant at $p<0.10$ level 
Fig. 8 Evaluated model. Note: **Significant at $p<0.01$ level, *Significant at $p<0.05$ level

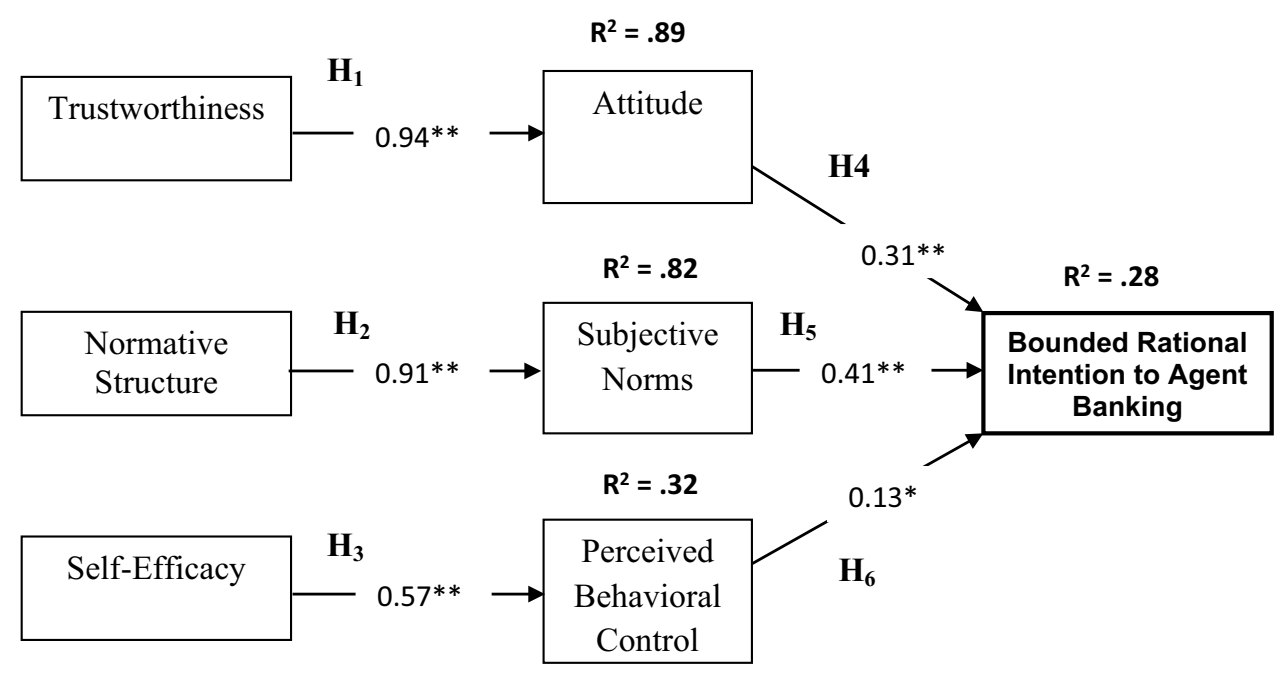

Note: **Significant at $p<0.01$ level, *Significant at $\mathrm{p}<0.05$ level

\begin{tabular}{lllc}
\hline Name of category & Name of index & Level of acceptance & $\begin{array}{c}\text { Values extracted } \\
\text { from fit model }\end{array}$ \\
\hline 1. Absolute fit & Chisq & $p>0.05$ & $p=0.656$ \\
& RMSEA & RMSEA $<0.08$ & RMSEA $=0.072$ \\
2. Incremental fit & GFI & GFI $>0.90$ & GFI $=0.912$ \\
& CFI & CFI $>0.90$ & CFI $=0.920$ \\
3. Parsimonious fit & TLI & TLI $>0.90$ & TLI $=0.913$ \\
\hline
\end{tabular}

Source: Hair et al. (2010); Zainudin, A. (2012) with subjective norms toward bounded rational intention to branchless banking $(\beta=0.91, p<0.001)$. So, H3 is strongly supported. Similarly, attitude $(\beta=0.31, p<0.001)$ has positive significant impact on bounded rational intention. Hence, $\mathrm{H} 2$ is supported. Besides, self-efficacy has noteworthy positive effect on perceived behavioral control toward bounded rational intention $(\beta=0.57, p<0.001)$ which supports $\mathrm{H} 5$. Finally, the positive effect of perceived behavioral control on bounded rational intention has also observed to be significant $(\beta=0.13, p<0.10)$ confirming H6 (Fisher, 1950, p. 80).

The evaluated model is presented in Fig. 8. Furthermore, the explanatory power of the predictors of a dependent variable in terms of coefficient of determination $\left(\mathrm{R}^{2}\right)$ was found by the path analysis represented in Fig. 8. The $\mathrm{R}^{2}$ value for attitude, subjective norm, perceived behavioral control and bounded rational intention is observed to be $0.89,0.82,0.32$ and 0.28 , respectively. The explanatory powers of both attitude and subjective norm are notably high. These $\mathrm{R}^{2}$ values indicate that the models have substantial explanatory power (Cohen, 1988). Finally, in Table 7 the model fit indices are demonstrated. All the fit indices such as absolute fit, incremental fit and parsimonious fit are within the acceptable ranges based on the recommendations provided by Hair et al. (2010) and Zainudin (2012).

\section{Discussion}

Grounded on TBRPB, this study explored the factors that influence the rural people's bounded rational intention toward branchless banking activities. More specifically, the effects of trustworthiness on attitude, normative structure on subjective norms, and self-efficacy on perceived behavioral control which, in turn, influence bounded rational intention toward branchless banking were investigated during the Corona Pandemic.

As an important underlying premise of the study is to examine the effect of the rural people's trustworthiness on attitude toward branchless banking intention, the results of the study indicate that trustworthiness has a very strong 
positive significant impact on attitude toward bounded rational intention to be involved in branchless banking conduct. This finding implies that the rural people are notably concerned about the reliability or trust which influence their attitude toward branchless banking behavior in the current Corona Pandemic. In reality, the instilled trust among the people toward the branchless banking services has exerted positive and significant impact in framing their rational intention. Since, branchless banking is the non-traditional and technologically modified financial product, building trust within the people regarding such product is essential. Once the people have started to believe the positive aspects of using branchless banking services, more intention would be involved in similar conduct. This evidence is supported by several studies in different diversified contexts (Akbari et al. 2019; Sembada and Koya 2019, George 2004).

The positive influence of normative structure on subjective norms toward bounded rational intention has also appeared highly significant. It indicates that normative structure toward subjective norms and finally to influence people's bounded rationality is geared up with the social influence, specifically by those people who have vital influence in the choice narrowing process during the current Pandemic in Bangladesh. Historically, people in Bangladesh are highly socialized and give more value to social and cultural norms. Thus, having the suggestions from the nearest and dearest persons, an individual tends to have more inclination to motivate the rural people to participate in branchless banking particularly during this emergency Corona Pandemic period in Bangladesh. This outcome corroborates several earlier studies in the other domains (George 2004; Taylor and Todd, 1998; Ashraf et al. 2019). The assumed positive effect of self-efficacy on perceived behavioral control and its consequential impact bounded rational intention has also appeared significant. Individuals with better skills and capabilities have greater control over their behavior which in turn expedites their bounded rational intent toward branchless banking. In the domain of online branchless banking behavior, this outcome is consistent with the numerous scholarly works (George 2004; Taylor and Todd, 1998; Ashraf et al. 2019a,b).

\section{Theoretical implications}

From a theoretical perspective, the present study shows the robustness of the concept of bounded rationality for aiding to explicate branchless banking intention behavior. As the concept of bounded rationality is subject to people's bounded self-interest, contextual information processing capacity, and bounded will power, the grounded research model fits well branchless banking intention during the contextual backdrop of the COVID-19 epidemic. Other studies have also successfully applied TBRPB as a theoretical framework which to explicate bounded rational intention toward $f$-commerce and Islamic microfinance borrowing activities (Ashraf 2018). In addition to the high significance of trustworthiness and normative structure, attitude, self-efficacy, subjective norm and perceived behavioral control have also found to be important to influence bounded rational intention of the rural people to involve in branchless banking activities during the Corona Pandemic. By doing so, this study successfully extended the basic TBRPB model in explaining the branchless banking behavior of rural people in some selected areas of Bangladesh. Thus, TBRPB has become proved once again as a valid theoretical underpinning in predicting bounded rational branchless banking intention particularly in a developing country context. This evidence demonstrates that more studies are needed in this theory domain for checking its robustness in other behaviors in question.

\section{Managerial implications}

From a managerial viewpoint, the results of this study imply that trustworthiness and normative structure are the most important factors to influence the branchless banking intention of the rural people in Bangladesh where the Corona Pandemic broke out with a severe effect. In reality, people in the rural areas are suspicious about the financial transaction online, because it is a risky job. Once it is misplaced, then it would be undoubtedly difficult to secure the fund again. Thus, it is evident that if branchless banking once proves to be reliable and effective, people will be more interested to engage in branchless banking for avoiding mass human interaction in the bank branches during this emergency situation of the Corona Pandemic. So, branchless banking would be a worthy alternative to branch baking for adopting security measure to be safe and free from catching the Corona virus.

At the same time, the findings of this study will help the bank authorities reduce the digital divide in Bangladesh to promote the further usage of digital banking channels through branchless banking in one of the fastest growing economies in south Asia. The present study also implies that as the overall banking industry has been facing unprecedented challenges during COVID-19 crises, public banks also have to come forward to open branchless banking in remote rural areas of the country. This initiative would help the public banks to be competitive as well as profitable during this emergency period of Corona Pandemic. Otherwise, these public banks have to face a serious consequence of financial loss and of their ultimate survivals.

\section{Limitations}

Like other studies, the present research also has a couple of drawbacks. First, the study selected trustworthiness, 
normative structure and self-efficacy as the explanatory variables to predict and explain about the branchless banking intention of the rural people in Bangladesh. There might be other important factors that could explain more the branchless banking intentional behavior. Second, the study employed the convenience random sampling procedure rather than simple random sampling which might produce more effective outcome to probe branchless banking intention. Lastly, during the present Corona Pandemic, data collection tasks were relatively cumbersome, because of violating maintenance of adequate social distance. Thus, the power of generalization of the present research's outcome is comparatively limited. Hence, future studies could address these limitations in future by which it would be easier to predict and explain about the branchless banking conduct in Bangladesh.

\section{Conclusion and scope for future research}

As mentioned earlier, the prime intent of this paper is to understand the impacts of the factors of intention of the rural people toward branchless banking behavior in Bangladesh during the Corona Pandemic. The results of the analysis reveal that instilled trust and attitude have significant influence on actual branchless banking behavior. More specifically, having trust on branchless banking operation not only expedites the peoples' bounded rational intention to utilize it, but also drives the people to exhibit the actual behavior for it. When the people perceive branchless banking operation as risk free or trustworthy, they have greater tendency to be involved in that activity. This outcome is supported by several earlier studies in heterogenic domains of activities (Anisimova et al. 2019; Oghazi et al. 2018). Moreover, individuals with bounded rational intention to have branchless banking services are basically moving forward to follow the real action of branchless banking operation. In the extant domain of marketing literature (Nystrand and Olsen 2020; Sultan et al. 2020), it is evident that peoples' intention to use branchless banking usually transmitted to their actual online branchless banking behavior.

As the Corona Pandemic has posed a serious threat to the economic condition as well as general people's overall wellbeing, the present study shows that the strategy of branchless banking is one of most effective alternatives to provide banking services to the people residing in remote areas. The results of this study also show that how branchless banking can be more popular to the general people of the country by making this type of banking more trustworthy and reliable which bears significant importance in reducing digital divide in Bangladesh. By way of branchless banking more people could be included in digital banking system in remote rural areas that will help the banking industry to be viable and conducive to achieve rapid economic growth of the country.

According to the suggestions advanced by the World Health Organization (WHO), one of the important precautionary measures to combat the Corona Pandemic is to maintain social distance by avoiding mass gathering in any type of social activities. In this regard, branchless banking is one of the best alternatives of banking maintaining that prescribed social distance. Thus, the present study has significantly contributed to consider this type of alternative banking to make people safe and continue the banking activities which will help the respective banks to be viable and effective in terms of providing financial services to the general people residing in rural areas of the country.

Based on the limitations stated in the earlier section, future research grounding on TBRPB could explore in other parts of Bangladesh where branchless banking is available and by this way the output of the current research would be easy to compare. Future studies could also incorporate other variables in their research models to explain and predict people's bounded rational intention toward branchless banking behavior of rural people residing in remote areas where the physical bank branch is not available. 


\section{Appendix}

Appendix: Interview Protocol

Comprehending the Intention to Use Branchless Banking by Rural People: A Survey

Location (Village, Upazila and District):

Interviewee (Title and Name): Interviewer:

$1=$ Strongly Disagree, $2=$ Disagree, $3=$ Somewhat Disagree, $4=$ Neutral, $5=$ Somewhat Agree, $6=$ Agree, $7=$ Strongly Agre e

\begin{tabular}{|c|c|c|c|c|c|c|c|c|c|}
\hline \multirow{5}{*}{ AT } & \multicolumn{2}{|r|}{ Items } & \multicolumn{7}{|c|}{ Opinion } \\
\hline & Q1 & I like to perform branchless banking during the present Corona Pandemic & 1 & 2 & 3 & 4 & 5 & 6 & 7 \\
\hline & Q2 & Performing branchless banking is a good idea during this Corona Pandemic & 1 & 2 & 3 & 4 & 5 & 6 & 7 \\
\hline & Q3 & Performing branchless banking is a wise idea during this Corona Pandemic & 1 & 2 & 3 & 4 & 5 & 6 & 7 \\
\hline & Q4 & Performing branchless banking would be pleasant for me during this Pandemic & 1 & 2 & 3 & 4 & 5 & 6 & 7 \\
\hline \multirow{6}{*}{ TR } & Q5 & Performing branchless banking is a reliable way for me during this Pandemic & 1 & 2 & 3 & 4 & 5 & 6 & 7 \\
\hline & Q6 & $\begin{array}{l}\text { Taking care of the safe financial matters of family through branchless banking is } \\
\text { a good idea during this Pandemic }\end{array}$ & 1 & 2 & 3 & 4 & 5 & 6 & 7 \\
\hline & Q7 & Branchless banking system is trustworthy during this Pandemic & 1 & 2 & 3 & 4 & 5 & 6 & 7 \\
\hline & Q8 & Putting trust in branchless banking is a good idea during this Pandemic & 1 & 2 & 3 & 4 & 5 & 6 & 7 \\
\hline & Q9 & I believe in the honesty of branchless banking during this Pandemic & 1 & 2 & 3 & 4 & 5 & 6 & 7 \\
\hline & Q10 & Believing in honesty of branchless banking is a good idea & 1 & 2 & 3 & 4 & 5 & 6 & 7 \\
\hline \multirow[t]{2}{*}{$\mathrm{SN}$} & Q11 & $\begin{array}{l}\text { People who influence my behavior would think that I should perform } \\
\text { branchless banking during this Pandemic }\end{array}$ & 1 & 2 & 3 & 4 & 5 & 6 & 7 \\
\hline & Q12 & $\begin{array}{l}\text { People who are important to me would think that I should perform branchless } \\
\text { banking during this Pandemic }\end{array}$ & 1 & 2 & 3 & 4 & 5 & 6 & 7 \\
\hline \multirow{6}{*}{ NS } & Q13 & My friends think that I should perform branchless banking during this Pandemic & 1 & 2 & 3 & 4 & 5 & 6 & 7 \\
\hline & Q14 & $\begin{array}{l}\text { Generally speaking, I want to do what my friends think I should do during this } \\
\text { Pandemic }\end{array}$ & 1 & 2 & 3 & 4 & 5 & 6 & 7 \\
\hline & Q15 & $\begin{array}{l}\text { My relatives would think that I should perform branchless banking during this } \\
\text { Pandemic }\end{array}$ & 1 & 2 & 3 & 4 & 5 & 6 & 7 \\
\hline & Q16 & Generally speaking, I want to do what my relatives think I should do & 1 & 2 & 3 & 4 & 5 & 6 & 7 \\
\hline & Q17 & $\begin{array}{l}\text { My parents would think that I should perform branchless banking during this } \\
\text { Pandemic }\end{array}$ & 1 & 2 & 3 & 4 & 5 & 6 & 7 \\
\hline & Q18 & Generally speaking, I want to do what my parents think I should do & 1 & 2 & 3 & 4 & 5 & 6 & 7 \\
\hline \multirow{3}{*}{$\mathrm{BC}$} & Q19 & I am capable of performing branchless banking during this Pandemic & 1 & 2 & 3 & 4 & 5 & 6 & 7 \\
\hline & Q20 & $\begin{array}{l}\text { Performing branchless banking is entirely within my control during this } \\
\text { Pandemic }\end{array}$ & 1 & 2 & 3 & 4 & 5 & 6 & 7 \\
\hline & Q21 & $\begin{array}{l}\text { I have the resources and the knowledge and the ability to perform branchless } \\
\text { banking during this Pandemic }\end{array}$ & 1 & 2 & 3 & 4 & 5 & 6 & 7 \\
\hline \multirow{5}{*}{ SE } & Q22 & $\begin{array}{l}\text { I feel comfortable performing branchless banking on my own during this } \\
\text { Pandemic }\end{array}$ & 1 & 2 & 3 & 4 & 5 & 6 & 7 \\
\hline & Q23 & $\begin{array}{l}\text { For me, feeling comfortable in performing branchless banking on my own is } \\
\text { important during this Pandemic }\end{array}$ & 1 & 2 & 3 & 4 & 5 & 6 & 7 \\
\hline & Q24 & If I want, I could easily do branchless banking on my own during this Pandemic & 1 & 2 & 3 & 4 & 5 & 6 & 7 \\
\hline & Q25 & $\begin{array}{l}\text { For me, being able to do branchless banking on my own is important during } \\
\text { this Pandemic }\end{array}$ & 1 & 2 & 3 & 4 & 5 & 6 & 7 \\
\hline & Q26 & $\begin{array}{l}\text { I would be able to do branchless banking on my own even if there is no one } \\
\text { around to help me during this Pandemic }\end{array}$ & 1 & 2 & 3 & 4 & 5 & 6 & 7 \\
\hline \multirow[t]{2}{*}{ IN } & Q27 & $\begin{array}{l}\text { I intend to perform branchless banking that inspires me to do this type of } \\
\text { banking during this Pandemic }\end{array}$ & 1 & 2 & 3 & 4 & 5 & 6 & 7 \\
\hline & Q28 & $\begin{array}{l}\text { I plan to perform branchless banking during this Pandemic, because I will be } \\
\text { able to avoid mass gathering in the bank }\end{array}$ & 1 & 2 & 3 & 4 & 5 & 6 & 7 \\
\hline
\end{tabular}




\section{Demographic Information:}

\section{Gender}

(C) Male $C$ Female

Age

(C. $15-25$ years

(c) 26-30 years

(C. 31-35 years

(C) $36-45$ years

C. Above 45 years

\section{Marital Status}

C Single

C Married

(C) Divorced/Separated

Religion

C. Islam

(C) Hinduism

(c) Others

Education

No Education $C$ Secondary $C$ Higher secondary $C$ Graduate \& Post graduate

\section{Monthly Income}

C $0-15,000$ BDT (200 USD)

C $15,001-25,000$ BDT (201 - 320 USD)

(C) $25,001-40,000$ BDT (321 - 500 USD)

(C) Above 40,000 BDT (Above 500 USD)

\section{Declarations}

Conflict of interest The author states that there is no conflict of interest.

\section{References}

Ahmed, J.U., and A. Ahmed. 2018. Agrani doer banking: Agent banking business in Bangladesh. Business Perspective and Research 6 (2): 154-164.

Thank You for Your Time

Ajzen, I. 1991. The theory of planned behavior. Organizational Behavior and Human Decision Processes 50: 179-211.

Akbari, M., Z.F. Ardekani, G. Pino, and H. Maleksaeidi. 2019. An extended model of theory of planned behavior to investigate highly-educated Iranian consumers' intentions towards consuming genetically modified foods. Journal of Cleaner Production 227: 784-793.

Alkailani, M. 2016. Factors affecting the adoption of internet banking: An external TAM model. Journal of Marketing Development and Competitiveness 10 (1): 39-52.

Anisimova, T., F. Mavondo, and J. Weiss. 2019. Controlled and uncontrolled communication stimuli and organic food purchases: The mediating role of perceived communication clarity, perceived 
health benefits, and trust. Journal of Marketing Communications 25 (2): 180-203.

Ariely, D. (2009). The end of rational economics. Harvard Business Review, July-August: pp. 78-85.

Ashraf, M.A. 2018. Use of bounded rationality theory to understand participation of rural women in Islamic microfinance: An analysis using SEM. Enterprise Development and Microfinance 29 (3\&4): 186-208.

Ashraf, M.A. 2019. Islamic marketing and consumer behavior toward halal food purchase in Bangladesh: An analysis using SEM. Journal of Islamic Marketing 10 (3): 893-910.

Ashraf, M.A., M.H.R. Joarder, and S.R.A. Ratan. 2019. Consumers' anti-consumption behavior toward organic food purchase: An analysis using SEM. British Food Journal 121 (1): 104-122.

Ashraf, M.A., M.D. Alam, and M.S.I. Noor. 2010. The influence of privacy and trust on the internet banking adoption in Bangladesh. Malaysian Management Journal 14 (1\&2): 13-23.

Bangladesh Bank (2020), Branchless banking statistics: Part-1. Bangladesh Bank, Dhaka, Bangladesh

Bandura, A. 1997. Self-efficacy: Toward a unifying theory of behavioral change. Psychological Review 84: 191-215.

Bandura, A. (1994). Self-efficacy. In: Corsini, R. J., Encyclopedia of Psychology, Wiley, New York Vol. 3, pp. 368-369.

Bandura, A. (2006). Guide for constructing self-efficacy scales. In :Pajares, F. and Urdan, T., Self-efficacy beliefs of adolescents, Information Age Publishing, Greenwich, CT, Vol. 5, pp. 307-337.

Bandura, A., and N.E. Adams. 1977. Analysis of self-efficacy theory of behavioral change. Cognitive Therapy and Research 1 (4): 287-310.

Bangladesh Bank (2013), Guidelines on Branchless banking service for the Banks, Bangladesh Bank, Dhaka, Bangladesh.

Bicchieri, C. 2006. The grammar of society: The nature and dynamics of social norms. Cambridge: Cambridge University Press.

Byrne, B.M. (2010), Multivariate applications series. Structural equation modeling with AMOS: Basic concepts, applications, and programming, Taylor and Francis Group, New York.

Cochran, W.G. 1977. Sampling techniques. New York, NY: John Wiley and Sons.

Chowdhury, M.M.H. (2018). Branchless banking service: A New Era in Banking. Daily Sun: Business Page. 9 October 2018

Chuah, S.H.W., P.A. Rauschnabel, M. Marimuthu, R. Thurasamy, and B. Nguyen. 2017. Why do satisfied customers defect? A closer look at the simultaneous effects of switching barriers and inducements on customer loyalty. Journal of Service Theory and Practice 27 (3): 616-641.

Corritore, C.L., B. Kracher, and S. Wiedenbeck. 2003. On-line trust: Concepts, evolving themes, a model. International Journal of Human-Computer Studies 58: 737-758.

Devi, J., and T., Pudaruth, S. and Ramdin, P. 2012. Factors influencing the adoption of Internet banking: A case study of commercial banks in Mauritius. World Journal of Science, Technology and Sustainable Development 9 (3): 204-234.

Devlin, J., C. Ennew, and H. Sekhon. 2015. Trust in financial services: Retrospect and prospect. Journal of Financial Services Marketing 20: 234-245.

Fisher, R.A. 1950. Statistical methods for research workers. London: Oliver and Boyd.

Fornell, C., and D.F. Larcker. 1981. Structural equation models with unobservable variables and measurement error. Journal of Marketing Research 18 (1): 39-50.

George, J.F. 2002. Influences on the intent to make Internet purchases. Internet Research 12 (2): 165-180.

George, J.F. 2004. the theory of planned behavior and internet purchase. Internet Research 14 (3): 198-212.
Hair, J.F., W.C. Black, B.J. Babin, R.E. Anderson, and R.L. Tatham. 2010. Multivariate data analysis: A global perspective. New York: Prentice Hall.

Hinson, R. 2011. Banking the poor: the role of mobiles. Journal of Financial Services Marketing 15: 320-333.

Hu, Z., S. Ding, S. Li, L. Chen, and S. Yang. 2019. Adoption Internet of fintach services for bank users: An empirical examination with an extended technology acceptance model. Symmetry 11: 1-16.

Huda, S.S., M.H. Kabir, N.N. Popy, and S. Saha. 2020. Innovation in financial services: The case of Bangladesh. Copernican Journal of Finance \& Accounting 9 (1): 31-56.

Jarvenpaa, S.L. and Todd, P.A. (1997). Is there a future for retailing on the Internet? In Peterson, R.A., Electronic Marketing and the Consumer, Sage, Thousand Oaks, CA, pp. 139-54.

Islam, S. (2018). The rapid growth of branchless banking service in Bangladesh. Dhaka Tribune: Business Page. 3 June 2018

Jolls, C., C.R. Sunstein, and R. Thaler. 1998. A Behavioral to approach to law and economics. Stanford Law Review 50: 1471-1550.

Jones, J.M., and L.R. Vijayasarathy. 1998. Internet consumer catalog shopping: Findings from an exploratory study and directions for future research. Internet Research 8 (4): 322-330.

Khan, A. R. and Woodard, J. (2016). Tipsheet: Branchless banking service 101, USAID's Mobile Solution Technical Assistance and Research Project (MSTAR). USAID, Washington

Khalifa, M., and M. Limayem. 2003. Drivers of Internet shopping. Communications of the ACM 46 (12): 233-239.

La Barbara, F., and I. Ajzen. 2020. Control interactions in the theory of planned behavior: Rethinking the role of subjective norm. Europe's Journal of Psychology 16 (3): 401-417.

Limayem, M., Khalifa, M. and Frini, A. (2000). What makes consumers buy from Internet? A longitudinal study of online shopping. IEEE transactions on systems, man, and cybernetics-Part A: Systems and humans, 30(4), 421-32.

March, J.G. 1978. Bounded rationality, ambiguity and the engineering of choice. Bell Journal of Economics 9: 587-608.

March, J.G., and J.P. Olson. 1976. Ambiguity and choices in organizations. Oslo: Universitetsforlaget.

Mukherjee, A., and P. Nath. 2003. A model of trust in online relationship banking. International Journal of Bank Marketing 21 (1): $5-15$.

Nasri, W., and L. Charfeddine. 2012. Factors affecting the adoption of Internet banking in Tunisia: An integration theory of acceptance and theory of planned behavior. Journal of High Technology Management Research 23 (1): 1-14.

Nystrand, B. T., and Olsen, S. O. (2020).Consumers' attitudes and intentions toward consuming functional foods in Norway. Food Quality and Preference 80, 103827.

Nisha, N., K. Nawrin, and A. Bushra. 2020. Agent banking and financial inclusion: The case of Bangladesh. International Journal of Asian Business and Information Management 11 (1): 127-141.

Oghazi, P., S. Karlsson, D. Hellström, and K. Hjort. 2018. Online purchase return policy leniency and purchase decision: Mediating role of consumer trust. Journal of Retailing and Consumer Services 41: 190-200.

Pavlou, P.A. (2002). What drives electronic commerce? A theory of planned behavior perspective. Academy of Management Proceedings, pp. A1-A6.

Podsakoff, P.M., and D.W. Organ. 1986. Self-reports in organizational research: Problems and rospects. Journal of Management 12 (4): 531-544.

Ratnasingham, P. 1998. The importance of trust in electronic commerce. Internet Research 8 (4): 313-321.

Sekhon, H., C. Ennew, H. Kharouf, and J. Delvin. 2014. Trustworthiness and trust: Influences and implications. Journal of Marketing Management 30 (3\&4): 409-430. 
Sembada, A. Y., and Koay, K. Y. (forthcoming) How perceived behavioral control affects trust to purchase in social media stores. Journal of Business Research.

Siddiquie, M. R. (2014). Agent banking, the revolution in financial service sector of Bangladesh", IOSR Journal of Economics and Finance. 5(1), 28-32.

Simon, H.A. 1986a. A behavioral model of choice. Quarterly Journal of Economics 69: 99-118.

Simon, H. A. (1986b). Rationality in psychology and economics. Journal of Business, 59, S209-S224.

Singh, S., and R.K. Srivastava. 2020. Understanding the intention to use mobile banking by existing online banking customers: An empirical study. Journal of Financial Services Marketing 25 (3\&4): 86-96.

Song, J. and Zahedi, F. (2001). Web design in e-commerce: a theory and empirical analysis.In: Proceedings of the 22nd International Conference on Information Systems, pp. 205-220.

Suh, B., and I. Han. 2003. The impact of customer trust and perception of security control on the acceptance of electronic commerce. International Journal of Electronic Commerce 7 (3): 135-161.

Sultan, P., Tarafder, T., Pearson, D., and Henryks, J. (2020). Intentionbehaviour gap and perceived behavioural control-behaviour gap in theory of planned behaviour: Moderating roles of communication, satisfaction and trust in organic food consumption. Food Quality and Preference 81, pp. 103838.
Tan, M., and T.S.H. Teo. 2000. Factors influencing the adoption of Internet banking. Journal of the Association for Information Systems 1 (5): 1-42.

World Bank (2017). The Global Findex Database 2017. World Bank, Washington, DC

Yu, P.L., M.S. Balaji, and K.W. Khong. 2015. Building trust in internet banking: A trustworthiness perspective. Industrial Management and Data Systems 115 (2): 235-252.

Yuan, Y., Lai, F. and Chu, Z. (2019). Continuous usage intention of internet banking: a commitment-trust model. Information Systems and e-Business Management. 17(1), pp.1-25.

Zanoli, R., and S. Naspetti. 2002. Consumer motivations in the purchase of organic food: A means-end approach. British Food Journal 104 (8): 643-653.

Zhao, A., N. Koenig-Lewis, and P. Ward. 2010. "Adoption of Internet banking services in China: Is it all about trust"? International Journal of Bank Marketing 28 (1): 7-26.

Zainudin, A. (2012). Structural equation modeling using AMOS graphics, Penerbitt Press, University Technology Mara, (UTM).

Publisher's Note Springer Nature remains neutral with regard to jurisdictional claims in published maps and institutional affiliations. 